\title{
The Public Space as an Articulating and Structuring Element for the Sustainable Urban Mobility. Case Study: Parking management in Villavicencio, Colombia
}

\author{
Carlos A. Moncada ${ }^{1}$, Diego A. Escobar ${ }^{2}$ \& Ximena C. Velandia ${ }^{3}$ \\ 1 Universidad Nacional de Colombia, Sede Bogotá. Facultad de Ingeniería, Departamento de Ingeniería Civil y \\ Agrícola, Ciudad Universitaria edificio 214 oficina 417, Bogotá, 111321, Colombia. E-mail: \\ camoncadaa@unal.edu.co \\ ${ }^{2}$ Universidad Nacional de Colombia, Sede Manizales. Facultad de Ingeniería y Arquitectura, Departamento de \\ Ingeniería Civil, Carrera 27 \# 64-60, Manizales, 170004, Colombia. E-mail: daescobarga@unal.edu.co \\ ${ }^{3}$ Universidad Nacional de Colombia, Sede Bogotá. Facultad de Ingeniería, Departamento de Ingeniería Civil y \\ Agrícola, Programa de Investigación en Tránsito y Transporte - PIT. Ciudad Universitaria edificio 214 oficina \\ 321, Bogotá, 111321, Colombia. E-mail: xcvelandiav@unal.edu.co \\ Correspondence: Diego A. Escobar, Universidad Nacional de Colombia, Sede Manizales. Facultad de Ingeniería \\ y Arquitectura, Departamento de Ingeniería Civil, Carrera 27 \# 64-60, Manizales, 170004, Colombia. E-mail: \\ daescobarga@unal.edu.co
}
Received: July 8, 2018
Accepted: July 27, 2018
Online Published: August 9, 2018
doi:10.5539/mas.v12n9p28
URL: https://doi.org/10.5539/mas.v12n9p28

The research is financed by Universidad Nacional de Colombia - Sede Bogotá.

\begin{abstract}
With the purpose of contributing to knowledge in parking management, this research based on sustainable mobility and the right to enjoy public space, aims to generate guidelines that promote an urban lifestyle centered on integration between different modes of transport, motorized and non-motorized. In this sense, a case study is included on parking management in the city of Villavicencio (department of Meta), in which an inventory and characterization of on-street and off-street car parks is presented as the main input. Based on this information, a methodology is proposed, aimed at guaranteeing off-street parking with capacities greater than 50 spaces, eliminating those with low capacity and relocating their demand in parking lots with higher capacities and low occupancy percentages. This will allow financial sustainability so that off-street parking can offer adequate security, infrastructure and fare conditions that make them more attractive compared to on-street parking areas. Additionally, it is proposed the elimination of parking on the road with access or exit to the arterial road and the elimination of areas for this type of parking that intersect with public transport routes or infrastructure for bicyclists.
\end{abstract}

Keywords: off-street parking, on-street parking, mobility management, public space, sustainable mobility

\section{Introduction}

Since the mid-twentieth century, with the rapid growth of motorized travel and in particular the growth of the use of private vehicles in urban areas, the planners recognized the conflict between the role of arterial roads for motorized transport and motorized transport functions demanded by the other users of these. The solution proposed at the time was to conceive the arterial roads and the general public space prioritizing its function for the mobility of motorized vehicles, for which reason it had to be separated from its other uses (including people) to avoid the conflicts that could present. This is how multifunctional arteries were seen as a problem for urban mobility (Mangones, 2007). In today's society, the mobility of people has acquired a much greater importance than it had in previous periods of the contemporary city. Proof of this is the relevance that this word has taken, not only in the urban and environmental discourse but also in the transport infrastructure plans and adaptation of the public space, even though these have been formulated with other objectives, more focused on the territorial articulation or economic development (Vallejo, 2012). This is how the roads present an important challenge to 
sustainable urban planning, since they try to solve four basic urban functions without having enough space. Arterial roads are the main channels for traffic among different areas of the city, provide access to buildings, are often important commercial areas, and serve as gathering or meeting points where residents and visitors meet their needs of leisure and meeting.

The incompatibility between the functions envisaged within the traditional conception of road projects and the actual uses that occur in these roads, cause the main inconvenience when intervening arteries and local roads, because sometimes there is no recognition of the mixed functions that these can offer. The urbanist François Ascher adds a new term for urban planners, which focuses on the street as a road inside an agglomeration that serves, either specifically or simultaneously, to cross an area of this agglomeration, to access places located along or immediately next to this road, and to produce collective space usable in various types of activities. A safe street, at least, has one of the following functions: transit, access (distribution) and reception (Ascher, 2007). In recent years, most Latin American countries have seen their vehicular fleet grow progressively, largely due to the increase in per capita income, which allows the population to acquire a private car. In turn, what for many people is a symbol of social status, comfort and class generates many negative externalities, such as increased fossil fuel consumption, higher levels of air pollution, road congestion and accidents, as well as greater infrastructure thought of in the automobile and not in other modes of transport that are friendlier to citizens and to the environment, among many others.

If you follow these trends in the region, you will soon reach cases where it is practically impossible to move within cities. For this reason, rather than prohibiting the use of private cars, measures are sought to rationalize their use and apply the specific parking instrument to generate positive changes in these negative trends (Banco Interamericano de Desarrollo [BID], 2013). Within the previous context, of the various uses that are given to the road, the authors do not consider the use of it as parking, which is a phenomenon increasingly common in large cities. Parking in pedestrian areas (sidewalks, crossings in the road) makes roads inaccessible to people with reduced mobility and discourages people from walking, which makes the urban environment less attractive and therefore reduces economic activity, also leading to people being more dependent on the automobile. For the sake of urban functionalism, efficiency in the use and occupation of land, and the consequent need for quick responses -not always thought and planned in the appropriate way- by the State towards a group of citizens with pressing needs in all sectors, the possibility of moving towards models of orderly and compact cities has been almost completely lost; the hope of an equitable and sustainable city is diluted over time as the partial, decontextualized and meaningless decisions that are daily experienced, become reality (Gibsone, Jolly, Vilches, \& Parra, 2011). The current situation in Latin America presents an opportunity to prevent the problem from progressing and congestion to reaches unsustainable levels, where finding solutions is truly complicated. It is through the incorporation of demand management policies and instruments that solutions can be given to the current situation in the region, and although many of these policies and planning instruments are not at all "popular" among the citizens and / or politicians, yes they can contain the current tendencies in the short and medium term of execution. Reducing travel time mitigates congestion and improves air quality while people feel good and move quickly from one destination to another (Xeros, 2014). This is how the parking management is consolidated as a fundamental tool for the management and recovery of public space for mobility, in order to optimize travel through the road network.

In this way the present investigation is structured in three parts: the first one, proposes an approach to the idea of public space as an articulating element of the different activities that intervene in the work of the city. From the study and definition of these concepts, the importance of the public space for the transformation of the different modes of transport is determined. In the second part, a case study on parking management is included in Villavicencio (Figure 1), a Colombian city, capital of the department of Meta with an area of 1,328 $\mathrm{km}^{2}$, located in the foothills of the Eastern mountain range to the north-west of the department, on the left bank of the Guatiquía River at a distance of $86 \mathrm{~km}$ from Bogotá, which has an urban population of 482,045 (Departamento Administrativo Nacional de Estadistica [DANE], 2005). This city constitutes an important regional and national node, due to its strategic location as a point of exit and entry of the Eastern Plains with its livestock, mining and agricultural products through the roads to Bogota and the rest of the country. As a result of the above, Villavicencio in areas of public and commercial use presents great dynamics that impact mobility, which generates the need for proper management of public space, in order to optimize travel through the road network and allow an equitable use for each of the actors on the road (Alcaldía de Villavicencio, 2018).

Within the case study, an inventory and characterization of parking lots on and off the road is presented as the main input. Based on this information, a parking management methodology is proposed, based on the analysis of the Vs capacity, the percentage of occupancy with the objective of classifying the parking lots according to this, 
to subsequently doing a graphic analysis that eliminates off-street parking with capacities lower than 50 spaces and / or with exit on the arterial road, relocating its demand in establishments with high capacities and low percentages of occupation. It also proposes the elimination of on-street parking to reduce road capacity affecting mass transport modes or infrastructure for bicyclists or pedestrians.

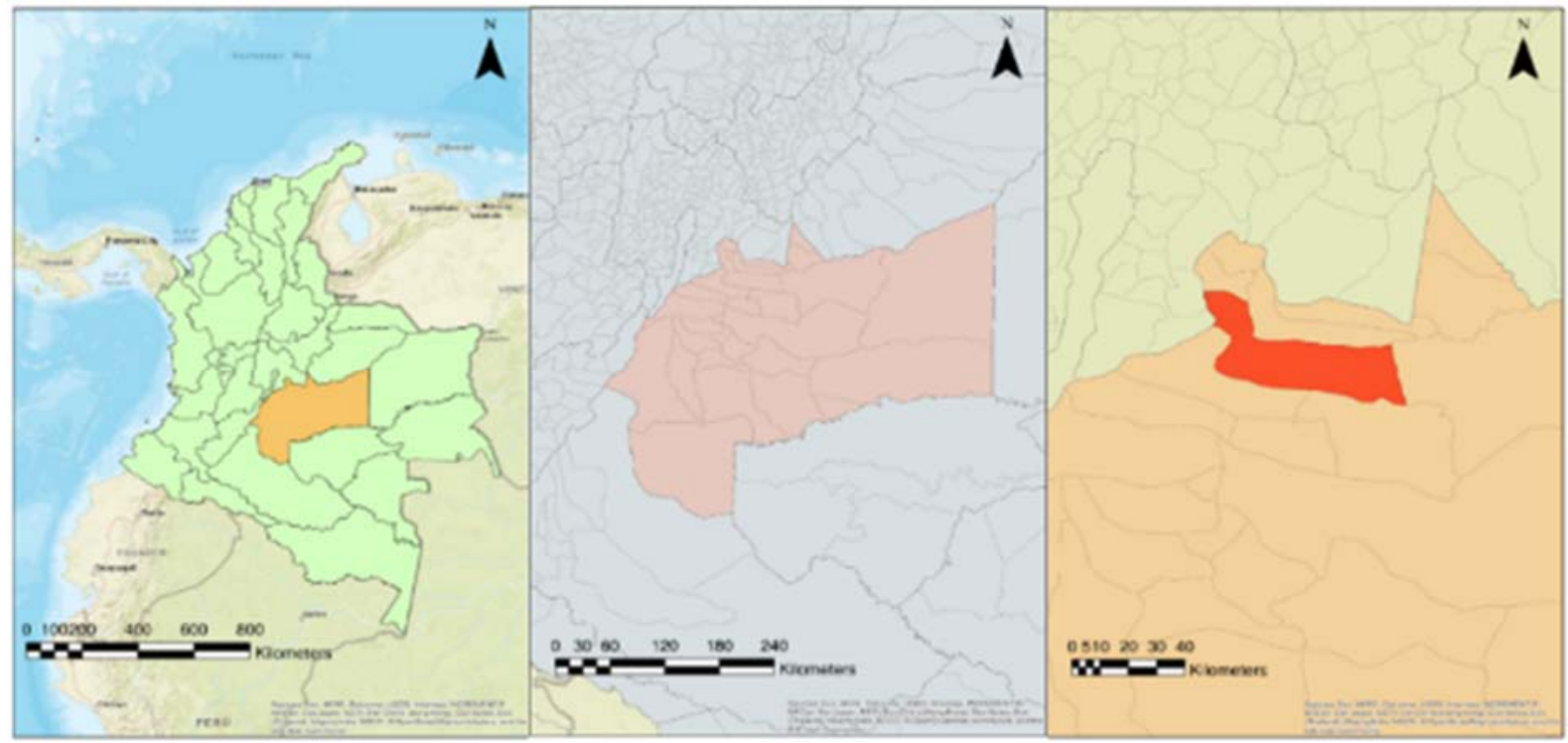

Figure 1. Geographic location of the city of Villavicencio. Source: Own elaboration using Qgis

\section{Method}

The methodology used in this research is composed of 4 main phases, which are presented in Figure 2: 1) Development of the concept of public space and realization of information gathering for characterization of parking lots; 2) Georeferencing of study points and information processing; 3) Analysis of parking supply and demand; 4) Analysis of parking conflicts with infrastructure for different modes of transport to private vehicles.

\subsection{Stage 1. Development of the Concept of Public Space and Realization of Information Gathering to Characterize the Parking Lots}

Initially an investigation of the concept of public space from different authors is made; parallel to this is the characterization of off-street parking from a survey that focuses on aspects such as rate, hours of operation, number of parking spaces for each mode of transport, occupation percentage and infrastructure conditions for the provision of the service (type of rolling surface, closed circuit television, type of ticket, etc.). Additionally, the characterization of on-street parking was made (Consortium of Permitted Parking Areas of Villavicencio, 2015), doing the rotation test by method of taking plates and observing the respective conditions of service.

\subsection{Stage 2. Georeferencing of Study Points and Information Processing}

Once the data is taken, the georeferencing of the parking lots is done on and off the road. The above in order to achieve graphical representation of the distribution of the parking in Villavicencio.

\subsection{Stage 3. Analysis of Parking Supply and Demand}

On this phase, an analysis of the supply and demand of off-street parking is made, contrasting the occupancy data with the capacity data obtained in the survey. Likewise, the analysis of the occupation of the zones where parking is allowed in the municipality is made, evaluating the possibility that the parking facilities have to partially or totally accommodate the demand of the parking areas on the road

\subsection{Stage 4. Analysis of Parking Conflicts with Infrastructure for Modes of Transport Different to Private Vehicles}

As a final step, the analysis of the conflicts that arise between the on-street parking areas and modes of transport different to the private vehicle is made, since using part of it as a parking space considerably reduces its capacity, and can generate reductions of the space destined to the cyclist and effects on the circulation of mass transit vehicles. According to the results of the analysis, alternatives are proposed for parking management focused on the recognition of public space as an articulating and structuring element for sustainable urban mobility. 


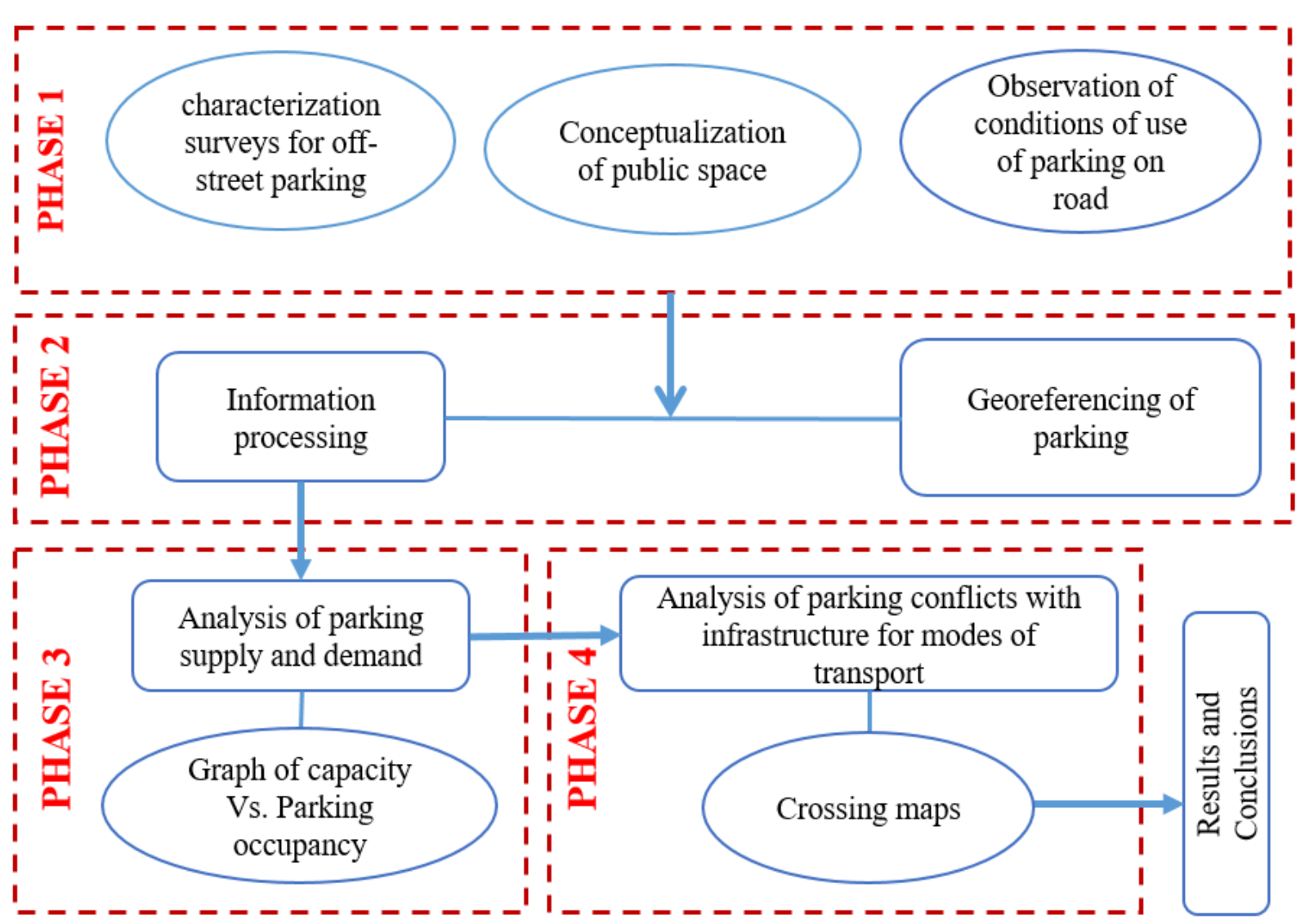

Figure 2. Research methodology

Source: self-made.

\section{Results and Discussion}

As a result of the analysis, a parking management methodology is proposed for the city of Villavicencio, which is structured as follows:

\subsection{Conceptualization of Public Space and Parking Management}

Currently one of the major topics of discussion in urban planning is the future of cities and therefore the project of urban life to which we aspire. Within this concern, the existence and role of public spaces plays a central role. For some authors, cities are disappearing at the expense of urban growth based on private logics, which opens the way to the development of the so-called diffuse city or fragmented city (Centeno, 2006). From this context it is important to understand that there are significant differences in the public space through the climatic zones, in different cultural and social contexts, and between the developed and developing world, in formal and informal parts of the city, as well as the use Flexible space by different groups of people over time. For the year 2011 at the 23rd Session of the UN-Habitat Council, the member states of the mandate of UN-Habitat consolidated the work throughout the agency on the public space, developing and promoting the policy of public space, coordination, dissemination of knowledge and directly help cities in public spatial initiatives. In the same way, the open working group of the UN in charge of drafting the Sustainable Development Goals 2016-2030 has proposed as the eleventh goal: "To build cities and human settlements that are inclusive, safe, resilient and sustainable. One of the proposed goals established in 2030 is to provide universal access to safe, inclusive and accessible, green and public spaces, especially for women and children, the elderly and persons with disabilities "(UN, 2015).

The solution to most parking problems is not glamorous or expensive, as this lies in the optimal management of parking on the road. Good management of on-street parking can end the chaos that normally exists, allowing the streets to run more efficiently and make them better places to be, making them safer. Parking management improves the conditions of local commerce, residents, and the operation of buses, bicycle users, pedestrians and users of all types of vehicles and enables the efficient and fair use of road space, alleviating local problems of 
low-cost transit and parking conflicts. At the same time, parking management helps establish a wider parking system in off-street establishments and promotes more sustainable urban mobility. All of the above is done at a low cost and sometimes even generates a surplus of income, since it is necessary to take into account that good management of on-street parking is necessary for all the crowded areas of all cities (Barter, 2016). "Parking spaces attract cars; so they generate congestion. Parking lots need space, which is not available for other uses of the road. Nothing else has changed the traditional urban landscape as dramatically as parked cars and has done so over the past decades "Hartmurt H. Topp, professor at the University of Kaiserslautern, Germany. Parking management is a powerful weapon with which cities can exert influence over transportation. By managing the offer, the design and the price of vehicular parking spaces, cities can exercise a high level of control over the flow and amount of traffic. In the past, cities used to expand the parking offer with the sole purpose of attracting more vehicles and at present the current parking policies adopt a more balanced vision, including social and environmental objectives to improve the quality of life in cities and the provision of equitable access to public space for all actors involved in mobility (Clean Air, 2015).

In Colombia there are particularly parking policies in which, on the one hand, the POTs establish parking minimums, forcing real estate developers to dedicate space for motor vehicles reducing the space to live, even for those who do not own a car ( 80 percent of Bogota families, for example). On the other hand, the municipal councils establish price limits for off-street parking and refuse to apply the parking charge authorized in the law of the development plan to cover the growing shortages of public transport. Barter (2016) recommends privileging management and not offering; ensure that parking meets the objectives of the street, make good use of the flexibility of drivers, support (with care) in the private sector and work with stakeholders to gain their support, among other strategies (Alcaldía de Villavicencio, 2013).

\subsection{Capability and Occupation Analysis}

According to the primary information, it was found that Villavicencio currently has 8,471 parking spaces from which $42 \%$ corresponds to quotas for motorcycles, $55 \%$ for automobiles, $2 \%$ for heavy vehicles and $1 \%$ for bicycles; it is observed that $47 \%$ of the parking capacity is concentrated in the downtown area. At the same time, 116 regulated parking areas were found, mostly located in the downtown area (See Figure 3).

These places have price control for the use of public space, managed between the mayor's office and with a concessionaire specialized in the subject. For authors like Barter, on-street parking is the opportunity to generate more orderly and safe streets, and at the same time, not only have resources for control, but also surpluses for improvement of public space and to improve the quality of public transport (Barter, 2016). Additionally, it is important to characterize the quality of the service provided by the parking lots. In this sense, as regards infrastructure, it was evident that $87 \%$ of the off-street parking lots are lots whose rolling surface is in affirmed or gravel. In addition, it was evidenced that, of the 161 parking lots that were studied, $65 \%$ of the establishments do not have CCTV (Closed Circuit Television), while $28 \%$ do provide this service. On the other hand, it is noteworthy that of these establishments, only $12 \%$ offer electronic tickets, which does not allow an adequate collection of the established rate. As for the rate, in the downtown area of Villavicencio where parking lots converge on and off the road, it was found that on average the cost of the hour-fraction in off-street parking corresponds to 2,300 pesos, while parking outside of via has a rate of 2,200 pesos. This is how, according to Rye, in cities where on-street parking is charged, it is often cheaper than off-street parking. As a result, people look for a space that is scarce on the road, while off-street parking lots remain half empty (Rye, 2011).

The fact that there are some spaces available for parking in the center of the city encourages people to drive to those areas, while congestion and pollution could be reduced by having fewer parking lots in the city to encourage people to use for a change, other modes of transport. According to the above, based on an analysis of capacity vs. the occupation of off-street parking lots (Figure 4), a classification of these was defined into four categories, such that parking spaces with capacities of less than 50 vehicles and occupancy of less than $60 \%$ are in category 1 (red)., in category 2 (yellow) the parking lots with capacities less than 50 vehicles and occupancy greater than $60 \%$, in category 3 (orange) the parking spaces with capacities greater than 50 vehicles and occupancy lower than $60 \%$ and in category 4 (green) parking with capacities greater than 50 vehicles and occupancy greater than $60 \%$.

Figure 5 proposes a scenario in which the parking lots located in quadrant 1 are eliminated due to their low capacity and low occupation percentage; the parking lots of quadrant 2, even with their low capacity, present high occupations, which is why it is proposed to relocate their demand in the establishments located in quadrant 3 , which have high capacities and occupations of less than $60 \%$. 


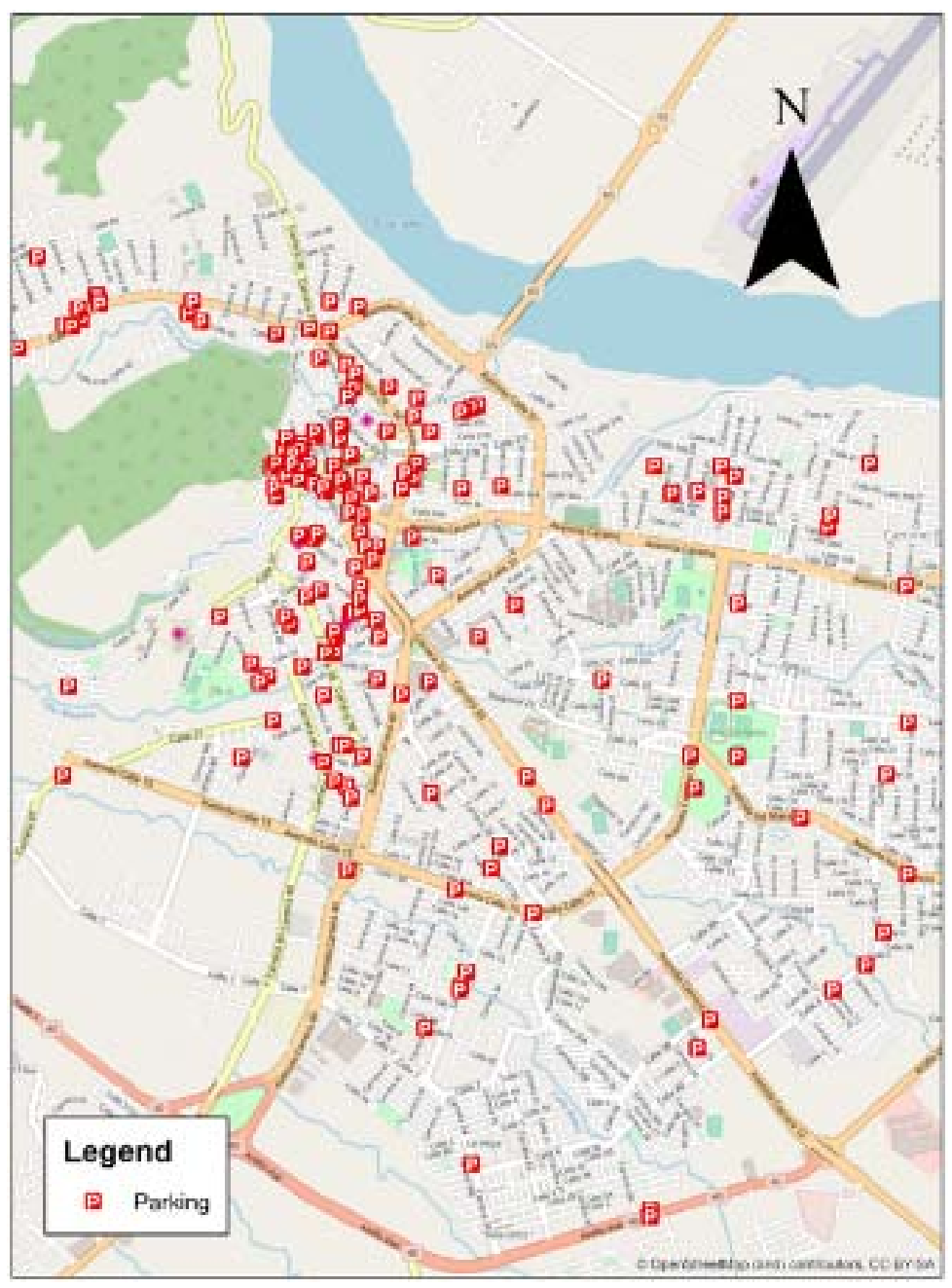

Figure 3. Location and distribution of parking lots in the city of Villavicencio. Source: Own elaboration using Google tools

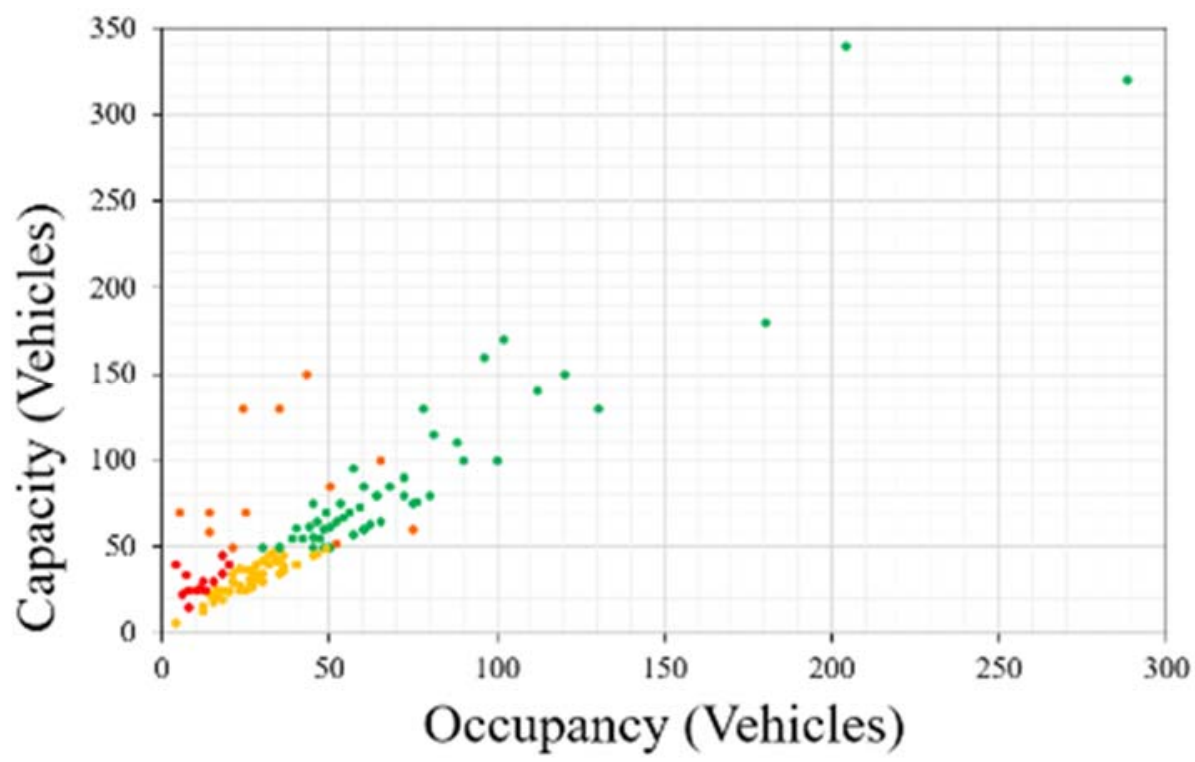

Figure 4. Classification of parking according to capacity and occupation percentage. Source: Own calculation 


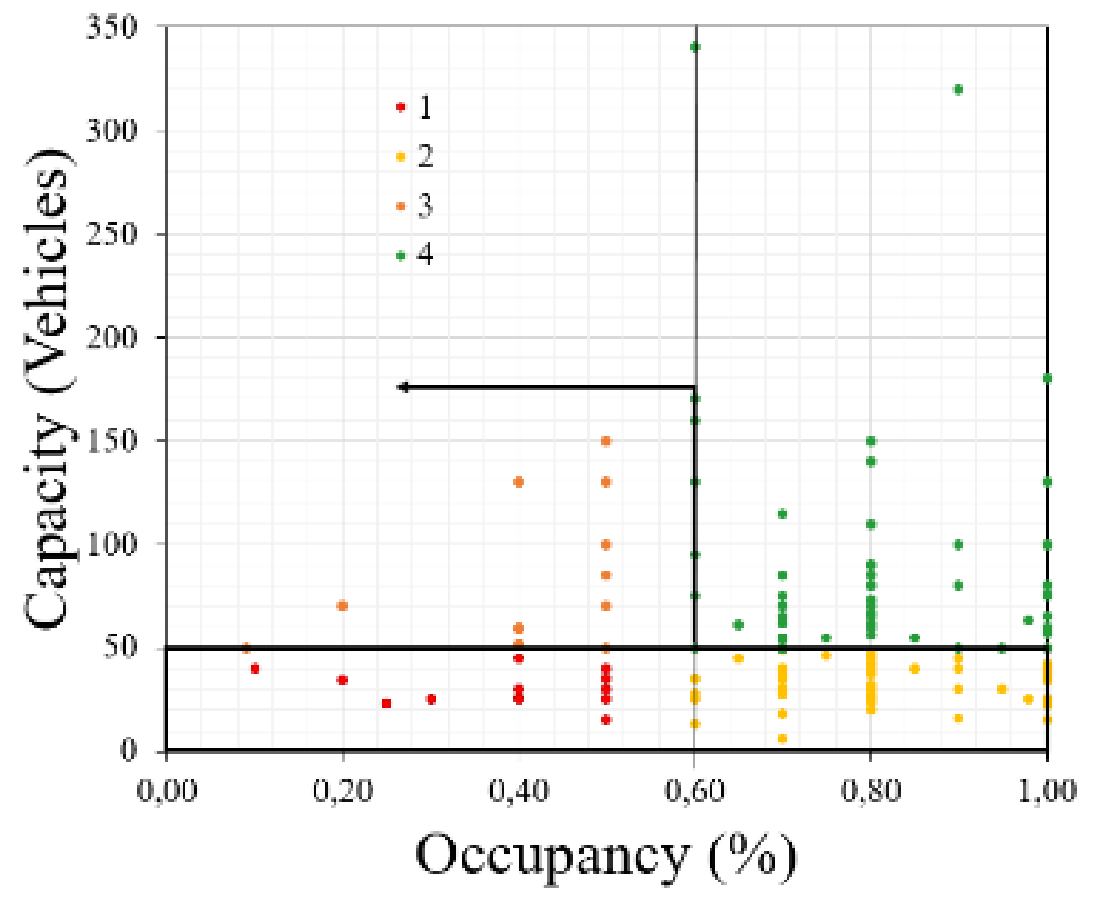

Figure 5. Classification of parking according to capacity and occupation percentage

Source: Own calculation.

The densities and their magnitudes, which show the heat maps, allow us to understand that the informal commerce This proposal, taking as a minimum capacity 50 vehicles, is done taking into account that it is important that the off-road parking facilities are more attractive than the on-street parking, therefore, good safety conditions, adequate infrastructure and a fair rate. These guarantees evidently imply costs that can only be assumed if off-road parking achieves a financial balance that allows it to be sustainable in the medium and long term. Another factor to consider is the interruption in the main roads flow that can be presented by the access or exit of parking vehicles, evidenced in Figure 6, which presents the geographical location of the parking lots according to the proposed classification, but also marked with an "star" parking with access or exit on a main road, which are proposed to be eliminated.

\subsection{Crossings of Parking Lots with Infrastructure for other Modes of Transport Different from Private Vehicles}

An analysis of the crossing between the on-street parking areas and the public transport and infrastructure routes for bicyclists was made, since one of the objectives of the proposed parking management methodology is to encourage the use of non-motorized and public transport, prioritizing them over the use of private vehicles. Figure 7 shows the parking areas in the municipality of Villavicencio, in which are represented in blue those that are active, i.e. those that represent an income for their use, and the inactive are presented in red, since they do not generate any monetary income for the municipality. Thus, it is evident that there is only one section on Avenue 40, where infrastructure for bi-users and parking areas converge; however, there is no conflict due to the road characteristics at this point. On the other hand, an analysis of the crossing between the on-street parking areas and the public transport routes was carried out (See Figure 8), from which it is recommended the elimination of the 8 parking areas on the road that present conflict with routes of the public transport system.

Additionally, it is important to note that to evaluate the location of the parking areas on the road, the average speed of the road corridors must be considered, which in the downtown area is considerably low. Likewise, it is established that the sections of the road must be wide enough so that the capacity of the road is not greatly affected by the location of parking areas on the road. Finally, the result of the management of parking lots on and off the road is shown on Figure 9. It is evident how the number of parking facilities was reduced from 161 to 46 and the active parking areas were reduced from 116 to 104, and the inactive ones were eliminated.

Due to everything that was mentioned before, it is important to note that the way in which a city develops is determined by a set of individual forces and interests, both the State and private organizations, which put together a complex plot. The relationship between all these agents is also dynamic, since it must change 
constantly depending on the specific conditions of each moment (Vasconcellos, 2010).

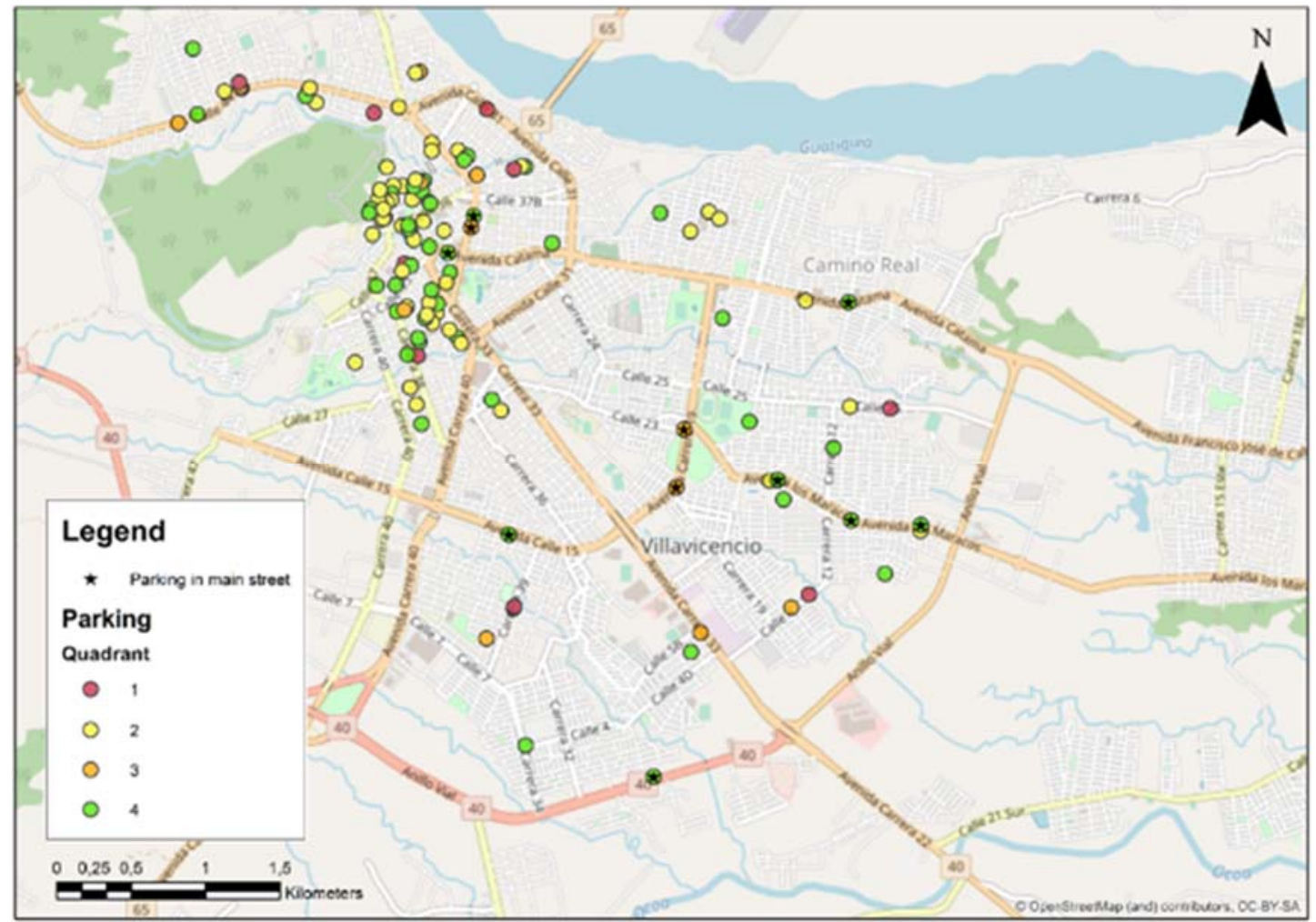

Figure 6. Off-street parking according to classification by capacity and occupation percentage with access or exit on a main road. Source: Own elaboration using Google tools

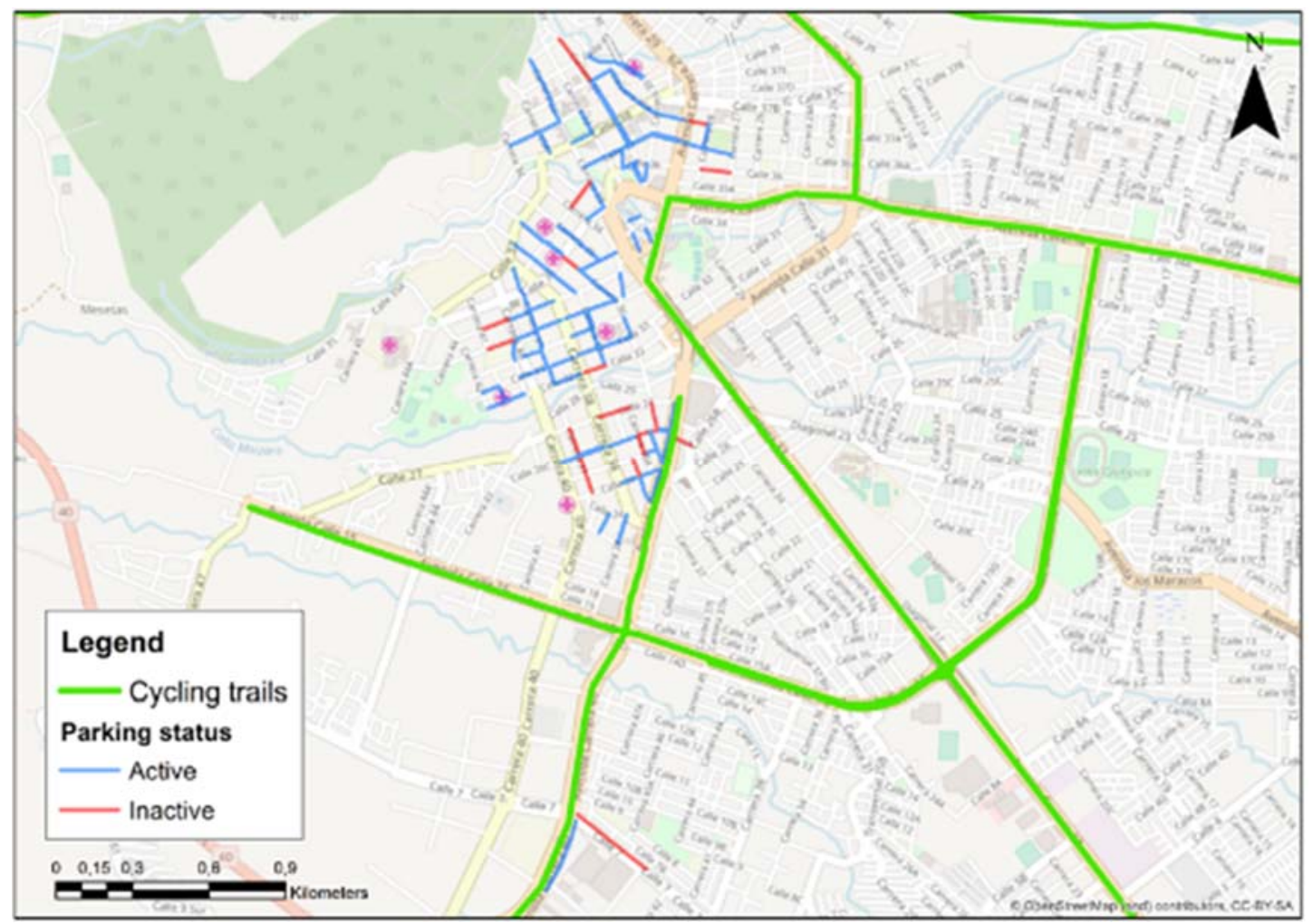

Figure 7. Crossings of parking lots with bicycle infrastructure. Source: Own elaboration using Google tools 


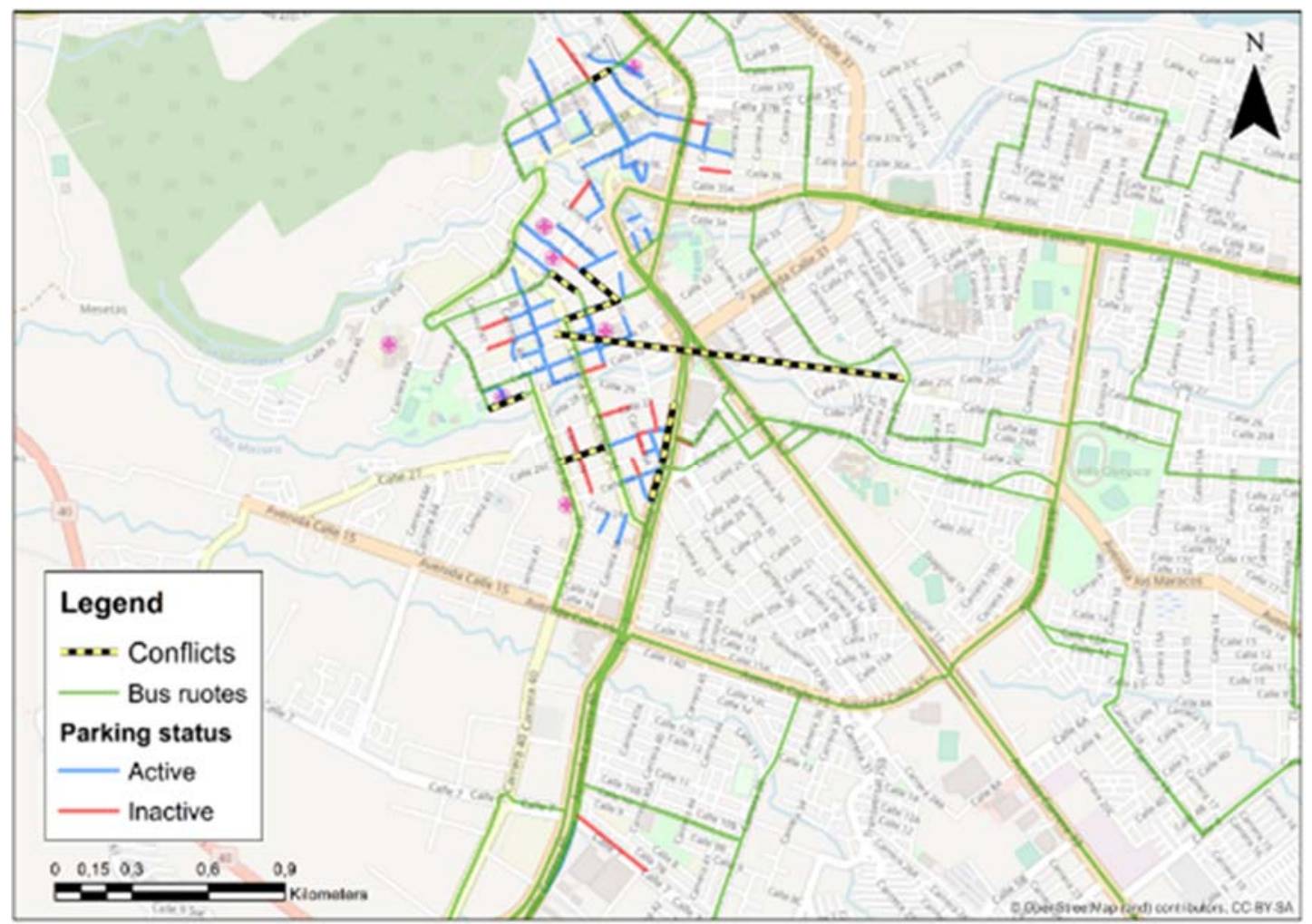

Figure 8. Crossings of parking lots with public transport routes. Source: Own elaboration using Google tools

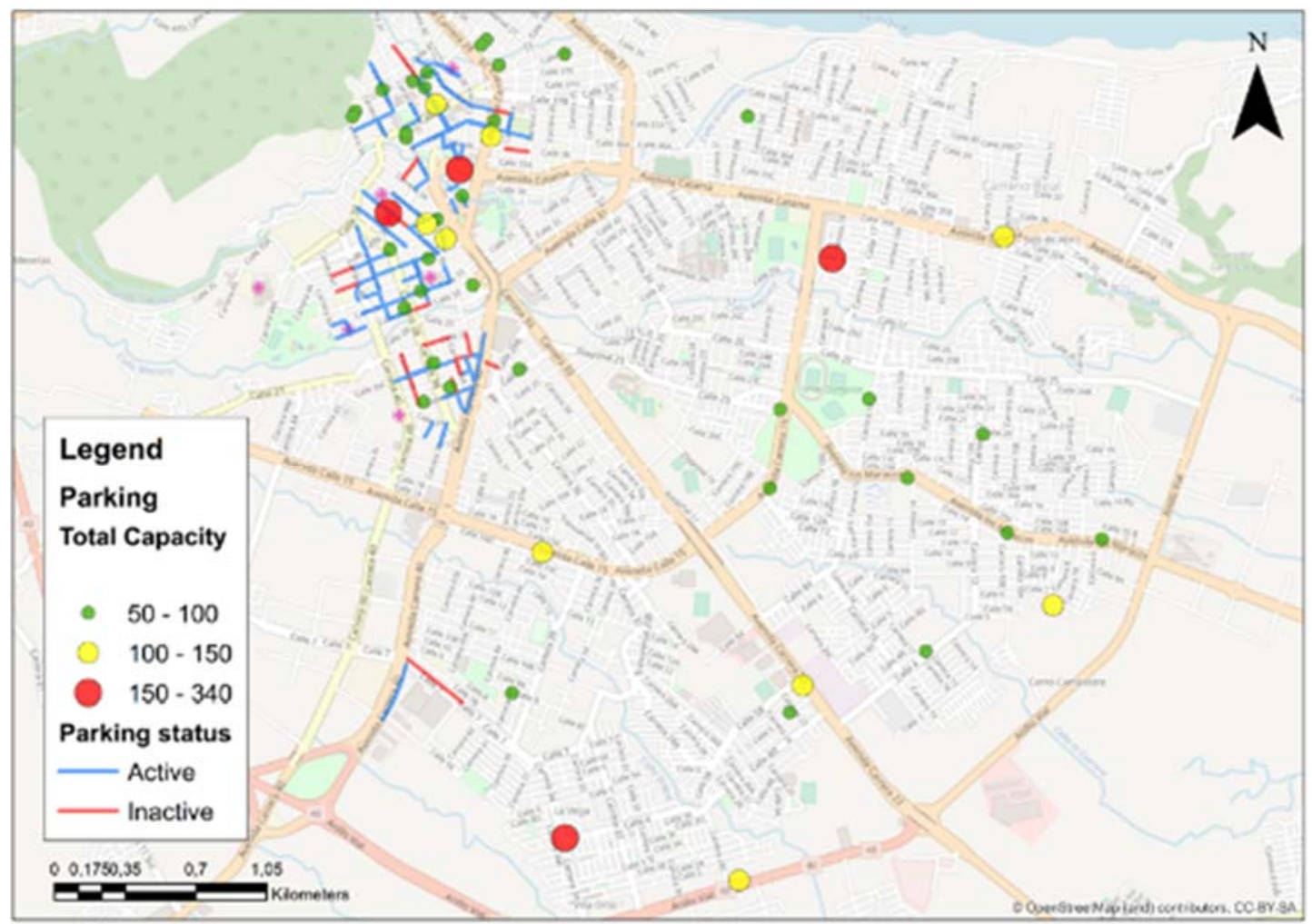

Figure 9. Result of parking management in the municipality of Villavicencio. Source: Own elaboration using Google tools 


\section{Conclusions}

The optimization of public space is very important to guarantee citizens the right to enjoy it, without affecting the commercial and service activities, so important especially in the central areas of cities. In recent years, most Latin American countries have seen their vehicular fleet grow progressively, largely due to the increase in per capita income, which allows the population to acquire a private car. At the same time, what for many people is a symbol of social status, comfort and class generates many negative externalities, such as increased fossil fuel consumption, higher levels of air pollution, road congestion and accidents, as well as greater infrastructure thought on the automobile and not in other modes of transport that are more friendly to citizens and to the environment, among many others.

If you follow these trends in the region, you will soon reach cases where it is practically impossible to move within cities. For this reason, rather than prohibiting the use of the private car, it is about looking for measures to rationalize its use and apply the specific parking instrument to generate positive changes in these negative trends.

It is for the foregoing that it is recognized that on-street parking is the opportunity to generate more orderly and safe streets, and at the same time not only have resources for control, but also surpluses for improvement of public space and to improve the quality of public transport. However, the fact that there are some spaces available for parking in the center of the city encourages people to drive there while congestion and pollution could be reduced by having fewer parking lots in the city to encourage people to use on the other hand, other modes of transport.

In that sense, it is proposed to take into account the following considerations to evaluate the location of the parking areas on the road: the average speed of the road corridors, which in the downtown area is considerably low; the section of the road, since it must be wide enough so that the capacity of this road is not greatly affected by the location of the parking area on the road and the use of land adjacent to these parking spaces.

Finally, this research proposed a parking management methodology, aimed at guaranteeing establishments with capacities greater than 50 spaces, eliminating parking spaces with low capacity to relocate their demand in places with high capacities and low occupancy rates, which allows financial sustainability so that off-street parking can offer adequate security conditions, infrastructure and rates that make them more attractive compared to the parking areas on the road.

Additionally, it was proposed the elimination of off-street parking with access or exit on the arterial road and the elimination of parking areas on the road that intersect with public transport routes or infrastructure for bicycle users since one of the objectives of the proposed methodology of parking management is to encourage the use of non-motorized and public transport, prioritizing them over the use of private vehicles, this in order not to reduce the capacity of the road, and reduce congestion.

\section{Acknowledgments}

The authors express their gratitude to the students of the Transit and Transportation Research Program of the National University of Colombia - Bogotá Headquarters.

\section{References}

Alcaldía de Villavicencio (2013). Formulación del Plan de Movilidad para el Municipio de Villavicencio: Informe 3. Informe de Formulación. Villavicencio.

Alcaldía de Villavicencio (2018). Alcaldía de Villavicencio - Meta. Obtenido de. Retrieved from http://www.villavicencio.gov.co

Ascher, F. (2007). Las dos formas de compartir la calle. Retrieved from http://www.redbcm.com.br/arquivos/bibliografia/ascher, $\% 20$ francois $\% 20-\% 201$ os $\% 20$ nuevos $\% 20$ principios $\% 20$ del\%20urbanismo.pdf

Banco Interamericano de Desarrollo - BID. (2013). Guía Práctica Estacionamiento y Políticas de Reducción de Congestión en América Latina. New York.

Barter, P. (2016). Gestión del Estacionamiento en Vía. Obtenido de. Retrieved from http://www.sutp.org/files/contents/documents/resources/B_Technical-Documents/GIZ_SUTP_TD14_on-str eet-parking-management_es.pdf

Centeno, P. V. (2006). El ESPACIO PÚBLICO: La movilidad y la revaloración de la ciudad (3 ed.). Lima: Departamento de Arquitectura $\quad$ - $\quad$ PUCP. $\quad$ Retrieved from http://repositorio.pucp.edu.pe/index/handle/123456789/28681 
Clean Air. (2015). Gestión sostenible del estacionamiento. Retrieved from http://www.cleanair-europe.org/fileadmin/user_upload/redaktion/downloads/BUND/10_B2_Update_Guidel ine___Parking_Management_ES.pdf

Consorcio de Zonas de Permitido Parqueo de Villavicencio. (2015). ZonaV. Obtenido de http://zonav.co/

Departamento Administrativo Nacional de Estadistica - DANE. (2005). Resultados y proyecciones (2005-2020) del censo 2005. Recuperado el 31 de Enero de 2017. Retrieved from https://www.dane.gov.co/index.php/estadisticas-por-tema/demografia-y-poblacion/proyecciones-de-poblaci on

Gibsone, C. D., Jolly, J., Vilches, A., \& Parra, F. (2011). Algunas reflexiones sobre la movilidad urbana en Colombia desde la perspectiva del desarrollo urbano. Papel Politico, 16(2), 485-514. Retrieved from http://www.scielo.org.co/pdf/papel/v16n2/v16n2a07.pdf

Mangones, S. C. (2007). Modelo Conceptual de Jerarquización de Vías Arterias en el Marco del Transporte Sostenible. Bogotá: Universidad Nacional de Colombia.

Organización de las Naciones Unidas -ONU. (2015). TEMAS HABITAT III: 11 - ESPACIO PÚBLICO. New York: Conferencia de Naciones Unidas sobre la Vivienda y el Desarrollo Sostenible. Obtenido de http://habitat3.org/wp-content/uploads/Issue-Paper-11_Public_Space-SP.pdf

Rye, T. (2011). Gestión de Estacionamientos: Una contribución hacia ciudades más amables. Eschborn: Dominik Schmid. $\quad$ Retrieved from https:/www.sutp.org/files/contents/documents/resources/A_Sourcebook/SB2_Land-Use-Planning-and-Dem and-Management/GIZ_SUTP_SB2c_Parking-Management_ES.pdf

Vallejo, M. H. (2012). El espacio de la movilidad urbana. Buenos Aires. Retrieved from http://www.cafedelasciudades.com.ar/imagenes\%20131/Indice_prologos_movilidad.pdf

Vasconcellos, E. A. \& Magrinyá F. (2010). Análisis de la movilidad urbana Espacio, medio ambiente y equidad. Retrieved from https://www.caf.com/media/3155/An\%C3\%A1lisis_movilidad_urbana.pdf

Xeros. (2014). Gestión Total de Estacionamientos. New York. Retrieved from https://www.xerox.com/downloads/esp/es/gdo/brochures/gdo_brochure_total_parking_management_es.pdf

\section{Copyrights}

Copyright for this article is retained by the author(s), with first publication rights granted to the journal.

This is an open-access article distributed under the terms and conditions of the Creative Commons Attribution license (http://creativecommons.org/licenses/by/4.0/). 